\title{
АДМІНІСТРАТИВНІ ІНСТРУМЕНТИ ЗАБЕЗПЕЧЕННЯ НЕЗАЛЕЖНОСТІ СУДДІВ В УКРАЇНІ
}

Данилевський М. A.

У статmі розкрито адміністративні інструменти забезпечення незалежності суддів як частини механізму правового регулювання, що об'єднують у собі зовнішній вираз адміністративних дій суб'єктів забезпечення незалежності суддів (форми адміністративної діяльності) та прийоми і способи впливу цих суб'єктів на адміністративні правовідносини в сфері гарантування незалежності суддів (методи адміністративної діяльності), які реалізуються в межах адміністративно-правових норм з метою створення усіх умов для безстороннього, самостійного, об'єктивного та справедливого правосуддя. Визначено, що формами адміністративної діяльності суб'єктів адміністративно-правового забезпечення незалежності суддів

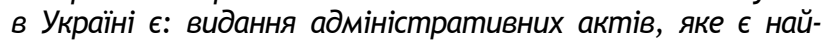
поширенішою формою, оскільки здійснюється органами суддівського врядування, органами суддівського самоврядування та іншими органами системи правосуддя, органами виконавчої влади (Президентом України, Міністерством юстиції України, правоохоронними органами тощо) та громадськістю; укладення адміністративних договорів; учинення інших юридично значущих адміністративних дій (реєстраційні діі суб'єктів адміністративно-правового забезпечення незалежності суддів); здійснення матеріально-технічних операцій; надання адміністративних послуг у сфері здійснення правосуддя. Зроблено висновки, що основними методами адміністративної діяльності суб'єктів адміністративно-правового забезпечення незалежності суддів в Україні є: заохочення (належне організаційне, матеріальне та соціальне забезпеченням судді); переконання (більш орієнтоване на протидію дифамації суддів та здійснення інформативно-аналітичної роботи щодо діяльності судової гілки влади); адміністративний примус (є основним методом, оскільки полягає у застосуванні заходів адміністративного примусу за посягання на суддівську незалежність); громадський контроль та нагляд (реалізується як спеціальними органами - Громадською радою доброчесності, так і громадськими організаціями з метою висвітлення діяльності суддів та підняття авторитету судової гілки влади в суспільстві).

Ключові слова: адміністративно-правові засади, незалежність суддів, принципи, спеціальна судова адміністрація, суддя.

В статье раскрыты административные инструменты обеспечения независимости судей как части механизма правового регулирования, объединяющие в себе внешнее выражение административных действий субъектов обеспечения независимости судей (формы административной деятельности) и приемы и способы воздействия этих субъектов на административные правоотношения в сфере обеспечения независимости судей (методы административной деятельности), которые реализуются в пределах административно-правовых норм с челью создания всех условий для беспристрастного, самостоятельного, объективного и справедливого правосудия. Определено, что формами административной деятельности субъектов

Данилевський М. А., 2019 административно-правового обеспечения независимости судей в Украине являются: издание административных актов, которое является самой распространенной формой, поскольку осуществляется органами судейского управления, органами судейского самоуправления и другими органами системы правосудия, органами исполнительной власти (Президентом Украины, Министерством юстиции Украины, правоохранительными органами и так далее) и общественностью; заключение административных договоров; совершение иных юридически значимых административных действий (регистрационные действия субъектов административно-правового обеспечения независимости судей), осуществление материально-технических операций; предоставление административных услуг в сфере правосудия. Сделаны выводы, что основными методами административной деятельности субъектов административно-правового обеспечения независимости судей в Украине являются: поощрение (надлежащее организационное, материальное и социальное обеспечение судьи), убеждение (более ориентировано на противодействие диффамации судей и осуществление информационно-аналитической работы о деятельности судебной ветви влаcтu), административное принуждение (является основным методом, поскольку состоит в применении мер административного принуждения за посягательство на судейскую независимость), общественный контроль и надзор (реализуется как специальными органами - Общественным советом добродетели, так и общественными организациями с целью освещения деятельности судей и повышения авторитета судебной ветви власти в обществе).

Ключевые слова: административно-правовые основы, независимость судей, принципы, специальная судебная администрация, судья.

The article describes the administrative instruments for ensuring the independence of judges as part of the mechanism of legal regulation, combining the external expression of the administrative actions of the subjects of ensuring the independence of judges (forms of administrative activity) and the techniques and methods of influence of these subjects on administrative legal relations in the sphere of guarantee independence of judges (methods of administrative activity) implemented within the limits of administrative and legal norms in order to create all conditions for an impartial, independent, fair and just justice. It is determined that the forms of administrative activity of the subjects of administrative and legal support of the independence of judges in Ukraine are: the issuance of administrative acts is the most widespread form, as it is carried out by the bodies of judicial administration, bodies of judicial self-government and other bodies of the justice system, bodies of executive power (President of Ukraine, Ministry justice of Ukraine, law enforcement agencies, etc.) and the public; conclusion of administrative contracts; committing other legally significant administrative actions (registration actions of the subjects of administrative and legal support of the independence of judges); implementation of logistical operations; provision of administrative services in the field of justice. It is concluded that the main methods of administrative activity of the subjects 
of administrative and legal support of the independence of judges in Ukraine are: encouragement (proper organizational, material and social security of a judge); persuasion (more focused on society to counteract judges' defamation and carry out information and analytical work on the activities of the judicial branch); administrative coercion (is the main method, since it involves the application of administrative coercion measures to encroach on judicial independence); public control and supervision (implemented both by special bodies - the Public Council of Integrity and public organizations in order to cover the activities of judges and to increase the authority of the judiciary in society).

Key words: administrative and legal support, organs of justice, legal means of justice, prosecutors, public administration, justice.

Актуальність теми. Сучасну правову державу неможливо уявити без незалежного правосуддя. Протягом майже чверті століття Україна декларує створення дійсно незалежної судової гілки влади, однак час від часу стикається з труднощами на шляху до реалізації цієї мети. 3 ростом громадської активності та моніторингу діяльності органів правосуддя з боку громадян стало очевидним, що дотримання принципу незалежності суддів $\epsilon$ важливим питанням, яке особливо турбує українське суспільство [8].

Крім того, питання незалежності суддів в Україні актуальне вже протягом десятиліть, шлях нашої держави до європейської інтеграції ще більше акцентує увагу на стані правосуддя в державі. Вища рада правосуддя та інші органи влади покликані вирішити низку завдань у судочинстві України, одне з яких - забезпечення незалежності правосуддя. Лише створення ефективно діючих механізмів перешкоджання впливу на суддю та його захист у разі будь-яких спроб втручання у здійснення ним правосуддя $\epsilon$ передумовою в утвердженні України як правової та демократичної держави [8].

Таким чином, оскільки незалежність судової гілки влади в Україні забезпечується через функціонування механізму правового регулювання, адміністративні інструменти забезпечення незалежності суддів, як елементи такого механізму, потребують ґрунтовного та комплексного дослідження.

Огляд останніх досліджень. Питанням незалежності судової влади в Україні займалися такі вчені, як В. Бойко, А. Борко, М. Закурін, А. Іванищук, Р. Ігонін, С. Кічмаренко, Д. Кулешов, В. Куценко, В. Лаговський, Т. Плугатар, І. Прошутя, С. Циганок та інші.

Однак, враховуючи те, що негативний вплив на суддів досі існує, необхідно комплексно дослідити адміністративні інструменти забезпечення незалежності суддів в Україні.

Мета статті полягає в тому, щоб за допомогою аналізу норм права та позицій вчених-юристів комплексно дослідити адміністративні інструменти забезпечення незалежності суддів.

Виклад основних положень. Поняття «адміністративні інструменти» досить нещодавно набуло масштабного поширення, оскільки попередньо до інструментів відносили лише форми адміністративної діяльності. Так, зокрема, А. Рибас визначила, що інструменти діяльності публічної адміністрації щодо призначення суддів в Україні - це засоби діяльності спеціальної публічної адміністрації Вищої кваліфікаційної комісії суддів України, Вищої ради правосуддя, Національної школи суддів України, зборів суддів, Президента
України щодо відбору та призначення суддів, які видаються у формах видання нормативних актів публічної адміністрації та індивідуальних адміністративних актів [7, с. 102-103].

Однак категорія «адміністративні інструменти» повинна бути розширена, на що вказує І. Патерило, який вважає, що необхідною та своєчасною виглядає заміна категорії «форми державного управління» поняттям «інструменти діяльності публічної адміністрації», під яким варто розуміти усю сукупність засобів (прийомів), які використовуються суб'єктами публічної адміністрації для регулювання суспільних відносин, що виникають у сфері публічного управління. Розвиваючи наведене визнання, вчений зазначає, що регулювання суспільних відносин може здійснюватися як через норми права, так і шляхом впливу на конкретних, індивідуалізованих суб'єктів адміністративно-правових відносин. Регулювання суспільних відносин може здійснюватися як у владному, так і невладному порядку. Зазначений висновок, з одного боку, суттєво розширює можливості публічної адміністрації, а з іншого - піднімає на принципово новий рівень приватних осіб, надаючи їм можливість впливати на зміст рішень суб'єктів публічної адміністрації [6, с. 283-289].

О. Нижник вказує, що з метою адаптації національного законодавства до законодавства Європейського Союзу та 3 огляду на необхідність удосконалення діяльності публічної адміністрації щодо належної реалізації прав і свобод громадян доцільно ввести в правовий обіг категорію «інструменти діяльності публічної адміністрації», під якою необхідно розуміти зовнішньо виражену дію органів публічної адміністрації, яка являє собою чітко визначену законом сукупність прийомів і засобів, застосування яких приводить до юридичних наслідків, що здійснюються в межах компетенції з метою виконання поставлених перед ними мети й завдань [5, с. 117-119].

Вищевказану позицію підтримав В. Галунько та зазначив, що інструмент публічного адміністрування - це зовнішній вираз однорідних за своїм характером і правовою природою груп адміністративних дій суб'єктів публічної адміністрації, реалізований у межах суворої відповідності визначеної законом компетенції меті досягнення бажаного для публічного адміністрування результату [2, с. 143].

Отже, адміністративні інструменти забезпечення незалежності суддів - це частини механізму правового регулювання, що об'єднують у собі зовнішній вираз адміністративних дій суб'єктів забезпечення незалежності суддів (форми адміністративної діяльності) та прийоми і способи впливу цих суб'єктів на адміністративні правовідносини в сфері гарантування незалежності суддів (методи адміністративної діяльності), які реалізуються в межах адміністративно-правових норм з метою створення усіх умов для безстороннього, самостійного, об'єктивного та справедливого правосуддя.

Тому, ґрунтуючись на нинішній теорії адміністративного права, до адміністративних інструментів забезпечення незалежності суддів слід віднести форми і методи адміністративної діяльності суб'єктів забезпечення незалежності суддів.

За характером і правовою природою форми діяльності суб'єктів публічної адміністрації поділяються на: 1) видання адміністративних, підзаконних нормативно- 
правових та індивідуальних адміністративних актів; 2) укладення адміністративних договорів; 3) учинення інших юридично значущих адміністративних дій; 4) здійснення матеріально-технічних операцій [1, с. 132].

Аналізуючи форми та методи адміністративної діяльності, варто вказати про заходи забезпечення суддівської незалежності. Спеціалізований Закон України «Про судоустрій і статус суддів» від 2 червня 2016 року № 1402-VIII визначає незалежність судів та незалежність суддів. Статтею 6 передбачено, що здійснюючи правосуддя, суди $\epsilon$ незалежними від будь-якого незаконного впливу. Суди здійснюють правосуддя на основі Конституції і законів України та на засадах верховенства права. Втручання у здійснення правосуддя, вплив на суд або суддів у будь-який спосіб, неповага до суду чи суддів, збирання, зберігання, використання і поширення інформації усно, письмово або в інший спосіб з метою дискредитації суду або впливу на безсторонність суду, заклики до невиконання судових рішень забороняються і мають наслідком відповідальність, установлену законом. Органи державної влади та органи місцевого самоврядування, їх посадові особи повинні утримуватися від заяв та дій, що можуть підірвати незалежність судової влади [9].

Стаття 48 Закону України «Про судоустрій і статус суддів» від 2 червня 2016 року № 1402-VIII передбачає незалежність судді. Так, суддя у своїй діяльності щодо здійснення правосуддя $\epsilon$ незалежним від будь-якого незаконного впливу, тиску або втручання. Суддя здійснює правосуддя на основі Конституції і законів України, керуючись при цьому принципом верховенства права. Втручання у діяльність судді щодо здійснення правосуддя забороняється і має наслідком відповідальність, установлену законом. Суддя не зобов'язаний давати жодних пояснень щодо суті справ, які перебувають у його провадженні, крім випадків, установлених законом. Незалежність судді забезпечується: 1) особливим порядком його призначення, притягнення до відповідальності, звільнення та припинення повноважень; 2) недоторканністю та імунітетом судді; 3) незмінюваністю судді; 4) порядком здійснення правосуддя, визначеним процесуальним законом, таємницею ухвалення судового рішення; 5) забороною втручання у здійснення правосуддя; 6) відповідальністю за неповагу до суду чи судді; 7) окремим порядком фінансування та організаційного забезпечення діяльності судів, установленим законом; 8) належним матеріальним та соціальним забезпеченням судді; 9) функціонуванням органів суддівського врядування та самоврядування; 10) визначеними законом засобами забезпечення особистої безпеки судді, членів його сім'ї, майна, а також іншими засобами їх правового захисту; 11) правом судді на відставку. Органи державної влади, органи місцевого самоврядування, їх посадові та службові особи, а також фізичні і юридичні особи та їх об'єднання зобов'язані поважати незалежність судді і не посягати на неї [9].

Таким чином, формами адміністративної діяльності суб'єктів адміністративно-правового забезпечення незалежності суддів в Україні $€$ :

1) видання адміністративних актів, яке $\epsilon$ найпоширенішою формою, оскільки здійснюється органами суддівського врядування (Вищою радою правосуддя, Вищою кваліфікаційною комісією суддів України), органами суддівського самоврядування та іншими органами системи правосуддя (Громадською радою доброчесності, Державною судовою адміністрацією України, Службою судової охорони, апаратом суду), органами виконавчої влади (Президентом України, Міністерством юстиції України, правоохоронними органами тощо) та громадськістю;

2) укладення адміністративних договорів;

3) учинення інших юридично значущих адміністративних дій (реєстраційні дії суб'єктів адміністративно-правового забезпечення незалежності суддів;

4) здійснення матеріально-технічних операцій (здійснюється в першу чергу Державною судовою адміністрацією України щодо матеріально-організаційного забезпечення суддів);

5) надання адміністративних послуг у сфері здійснення правосуддя.

Основними методами адміністративного права $\epsilon$ заохочення, переконання і примус [1, с. 132-144]. Сутність заохочення полягає в тому, що воно стимулює учасників адміністративно-правових відносин на належну поведінку: заохочення призначено для стимулювання активної діяльності суб'єктів адміністративного права, формування правомірної поведінки, зміцнення засад справедливості та дисципліни в адміністративно-правовому регулюванні [1, с. 132-144].

За допомогою заходів переконання стимулюється належна поведінка учасників адміністративно-правових відносин. Переконання виявляється у використанні різних роз'яснювальних, виховних, організаційних заходів для формування волі суб'єктів адміністративного права або ії корекції. Тим самим особи добровільно підпорядковуються юридичним приписам і свідомо беруть участь у їх виконанні. Найпоширеніші форми його використання публічною адміністрацією: 1) здійснення систематичної роз'яснювальної роботи щодо норм адміністративно-правових актів (агітаційно-пропагандистська робота); 2) критика антигромадських вчинків; 3) інформування населення про стан забезпечення правопорядку; 4) заохочення громадян, які беруть участь в охороні правопорядку [1, с. 132-144].

Адміністративний примус - це визначені нормами адміністративного права заходи фізичного або психологічного впливу публічної адміністрації на фізичних та юридичних осіб - у вигляді особистих, майнових, організаційних обмежень їх прав, свобод та інтересів у випадках вчинення цими особами протиправних діянь або в умовах надзвичайних обставин, з метою попередження та припинення протиправних діянь, забезпечення провадження в справах про правопорушення, притягнення винних осіб до відповідальності, попередження та локалізації наслідків надзвичайних ситуацій [4, с. 18].

Висновки. Таким чином, основними методами адміністративної діяльності суб'єктів адміністративно-правового забезпечення незалежності суддів в Україні $\epsilon$ :

1) заохочення (належне організаційне, матеріальне та соціальне забезпеченням судді);

2) переконання (більш орієнтоване на протидію дифамації суддів та здійснення інформативно-аналітичної роботи щодо діяльності судової гілки влади);

$3)$ адміністративний примус (є основним методом, оскільки полягає у застосуванні заходів адміністративного примусу за посягання на суддівську незалежність);

4) громадський контроль та нагляд (реалізується як спеціальними органами - Громадською радою добро- 
чесності, так і громадськими організаціями з метою висвітлення діяльності суддів та підняття авторитету судової гілки влади в суспільстві).

\section{Література}

1. Галунько В.В., Курило В.І., Короєд С.О. та інше. Адміністративне право України. Т.1. Загальне адміністративне право : навчальний посібник. Херсон : Грінь Д.С. 2015. 272 c.

2. Галунько В., Діхтієвський П., Кузьменко О., Стеценко С. та інші. Адміністративне право України. Повний курс: підручник. Херсон : ОЛДІ-ПЛЮС, 2018. 446 с.

3. Кічмаренко С.М. Адміністративно-правове забезпечення незалежності судової влади в Україні : дис. ... канд. юрид. наук : 12.00.07. Науково-дослідний інститут публічного права, Київ, 2017. 238 с.

4. Коломоєць Т.О. Адміністративний примус у публічному праві України: теорія, досвід та практика реалізації : автореф. дис... д-ра юрид. наук : 12.00.07. Х., 2005. 38 с.

5. Нижник О. Адміністративно-правові інструменти реалізації державної регіональної політики у сфері вищої освіти. Підприємництво, господарство і право. 2016. № 2. C. 117-121.

6. Патерило І.В. Інститут інструментів діяльності публічної адміністрації у системі адміністративного права України. Науковий вісник Дніпропетровського державного університету внутрішніх справ. 2013. № 1. С. 283-289.

7. Рибас А.В. Інструменти діяльності публічної адміністрації при призначенні суддів в Україні. Юридична наука. 2015. № 11. С. 99-103.

8. Сліпенюк В.В. Забезпечення незалежності суддів як одне із завдань Вищої ради правосуддя. Правова держава. 2017. URL: http://dspace.onu.edu. ua:8080/bitstream/handle/123456789/11087/19-24. pdf? sequence $=1$ \&isAllowed $=y$.

9. Про судоустрій і статус суддів: Закон України від 02.06.2016 № 1402-VIII. Відомості Верховної Ради. 2016. № 31.

Данилевський М. А., асnірант Науково-дослідного інституту публічного права 